\title{
Reasons for the poor employability of the first degree in students' perceptions
}

Sin, Cristina ${ }^{a}$ and Tavares, Orlanda ${ }^{b}$

${ }^{a}$ Centro de Investigação de Políticas do Ensino Superior (CIPES), Portugal and Universidade de Aveiro, Departamento de Ciências Sociais, Políticas e do Território, Portugal. ${ }^{\mathrm{b}}$ Centro de Investigação de Políticas do Ensino Superior (CIPES), Portugal and A3ES, Portugal

\begin{abstract}
The reduction of the first degree in Portugal, driven by the Bologna reforms, has resulted in a perceived loss of its value in the society and the labour market. The implementation of the reforms coincided with the severe economic crisis and the job scarcity currently affecting the labour market. This paper aims to investigate student perceptions of the reasons why they consider the first degree insufficient. Is it because students really feel unprepared for the labour market as a result of the shorter first degree or is it because of the widespread perception in the society that the first degree is insufficient? In other words, is the poor employability of the first degree perceived as being determined by individual inability or by an external scepticism about its value? Findings suggest that, for students, the first degree is not enough mostly because of their individual inability to respond to labour market needs and less because of public scepticism about the degree's worth. Therefore, students apparently see themselves as the key agents, emphasising their own responsibility for employability and the individual factors behind the employability concept, although the latter are somewhat balanced by external factors under the weight of the economic crisis.
\end{abstract}

Keywords: First degree; Employability; Higher education; Student perceptions; Bologna process; Portugal 


\section{Introduction}

Further to the Bologna process and the reorganization of the degree architecture, the value of the shortened first degree for the labour market was debated in various European countries (Schomburg and Teichler 2011). Fears of poor employability of the degree have been mostly confirmed in Southern European countries. On the contrary, in countries with more solid economies, like Germany or Austria (Schomburg and Teichler 2011), the fears about the acceptance of the new bachelor degrees on the labour market proved to be unjustified, as most bachelor graduates were neither unemployed, not in poor/precarious employment. However, in Portugal, a country which has been facing serious economic constraints and job scarcity, previous studies (Cardoso et al. 2012; Sin et al. 2016a, 2016b; Vieira and Marques 2014) have shown that the first degree has lost credibility for the labour market, after it was shortened from $4 / 6$ years to $3 / 4$ years.

Considering these two different contexts, how do students, in a country where the first degree has depreciated, interpret this lost of value? Is it because students feel they are effectively unprepared for the labour market or is it because they internalise the widespread perception in the society that the first degree is insufficient? In other words, the paper explores whether the poor employability of the first degree is perceived as being determined by individual inability or as being determined by an external scepticism about its value.

\section{Individual versus external factors for employability}

There are two main dimensions to keep in mind in the interpretation of employability. A first one is the absolute dimension (Brown et al. 2003) which comprises individual abilities, attributes and pro-active dispositions (Fugate et al. 2004; Van der Hejde and Van der Hejden 2006). For example, Fugate et al. (2004, 15) define employability as 'a psychosocial construct that embodies individual characteristics that foster adaptive cognition, behaviour and affect, and enhance the individual-work interface'. Such conceptualisations fail to acknowledge contextual determinants which may be equally responsible for an individual's professional success. Thus, external factors, beyond an individual's control, that determine employability must also be acknowledged. These make up the relative dimension (Brown et al. 2003), which is related to external factors such as the macroeconomic situation and the state of the labour market (MacQuaid and Lindsay 2005), individuals' relative position compared to other job-seekers (Brown et al. 2003), or employer preferences and discrimination (Cai 2013). For higher education graduates, employability is further conditioned by institutional brand and reputation and field of study (Rothwell et al. 2008; Jackson 2014). In the current Portuguese context and the reform of the degree structure, the perceived devaluation of the first degree (Cardoso et al. 2012; Sin 
et al. 2016a) can be seen as another external factor that determines the employability of first degree holders.

The two dimensions of employability have not been equally acknowledged in recent labour market and employment policies. In particular, the relative, external dimension has been played down. Dominant political discourses have been focusing on the individual dimension, promoting individual responsibility for employability, marking a policy shift away from a focus on fostering employment (a state obligation) towards fostering employability (an individual obligation) (Bridgstock 2009; Brown et al. 2003; McQuaid and Lindsay 2005). Policy-makers see employability as the possession of attributes (Holmes 2013), holding individuals responsible for their professional success/failure. This tendency was critically designated as the 'politics of blame' (Thrupp 1998), whereby failure is attributed to individuals rather than to the policies themselves. These conceptual tools, which reflect the complexity of the employability construct, will be used as the theoretical lens to explore students' opinions as to the poor employability of the first degree.

\section{Methodology}

Data were collected in 2015 through focus groups interviews. Around 70 students in the last year of the first degree from a selection of disciplinary areas - Arts/Design, Computer Engineering and Management - participated in the focus groups (5 to 6 in each group). The disciplines were chosen in order to capture the disciplinary variation regarding the hard/soft and pure/applied dimensions (Becher and Trowler 2001) and to give insight into potentially contrasting differences by discipline. Additionally, and also to explore possible differences, the selected students belonged to the four institution types present in Portuguese higher education: public/private and university/polytechnic (see Table 1). Universities are research-oriented, while polytechnics have a vocational mission and are responsive to local economic needs. Discussions were held separately, in each discipline and in each institution. 
Table 1. Institutions and study programmes which participated in the focus groups

\begin{tabular}{|c|c|c|}
\hline Institution & Type & Study programmes \\
\hline Institution A & Public University & $\begin{array}{l}\text { Arts } \\
\text { Computer Engineering } \\
\text { Management }\end{array}$ \\
\hline Institution B & Public Polytechnic & $\begin{array}{l}\text { Visual Arts and Arts Technology } \\
\text { Computer Engineering } \\
\text { Tourism Management/Business Studies }\end{array}$ \\
\hline Institution $\mathrm{C}$ & Private University & $\begin{array}{l}\text { Design } \\
\text { Computer Engineering } \\
\text { Management (or Hospitality Management) }\end{array}$ \\
\hline Institution D & Private Polytechnic & $\begin{array}{l}\text { Computer Engineering } \\
\text { Management }\end{array}$ \\
\hline Institution $\mathrm{E}$ & Private Polytechnic & Arts (Illustration/Graphics/Multimedia) \\
\hline
\end{tabular}

The discussions explored the participants' understanding of the meaning of employability, their perceptions about the employability of the first degree and who they held responsible for employability. Discussions were transcribed and analysed with the help of the qualitative analysis software MaxQDA, following a grounded theory method (Strauss and Corbin 1990). In the case of students' understanding of employability, two major categories emerged: one which framed employability around external factors and another which focused on individual factors. In the case of the employability of the first degree and its value for the labour market, the following categories stood out: essential, sufficient, insufficient, career development. Regarding the attribution of responsibility for employability, the categories were: students, higher education institutions, employers and policy-makers. 


\section{Findings: Reasons for the (in)sufficiency of the first degree}

The majority of opinions pointed to the insufficiency of the first degree for the labour market, with only few perceptions that the first degree was sufficient for employment. As previous research (Sin et al. 2016a; Cardoso et al. 2012) has already suggested, students appear to regard the master degree as the new positional good to get competitive advantage or to avoid unemployment. Nevertheless, a minority of students who had already been employed for several years, all of them studying in private institutions, attached value to the first degree as a means of career progression or development.

When explaining why they believed the first degree was not enough, students invoked feelings of unpreparedness to start working, which were frequently related to a perception of compression of the study cycle further to the Bologna reforms. As a result, they thought they did not have time enough to acquire the knowledge and competencies they would need on the labour market. However, the perception of insufficiency was also based on the fact that, according to students, the society itself believed the degree was not enough, although this was less frequent (and mainly encountered among students in public institutions) than the feeling of unpreparedness. Therefore, the perception they themselves were lacking knowledge and competences necessary in a future job was stronger than the perception that the society did not value the first degree, which suggests that, in students' views, the first degree is not enough more because of individual inability than because of public skepticism. This assumption is strengthened by the way in which students understand both the responsibility for employability and the concept of employability itself, dimensions in which their role as active agents stands out.

That students attributed the poor employability of the first degree primarily to their own unpreparedness for the labour market also suggests that they feel they are the ones responsible for being employable (see also Sin et al. 2016b). In fact, when asked to whom they attributed the main responsibility for employability, the overwhelming opinion was that students themselves were the main responsible, and in a lesser degree higher education institutions and employers. However, this overall finding hides some interesting variations. It is noteworthy that students in polytechnic institutes regarded this responsibility as rather balanced between three actors: themselves, higher education institutions and employers. Since polytechnics are vocational institutions meant to respond to the economic needs of their region, students have higher expectations from their institution and from employers to develop a closer relationship which would result in employment. 
Table 2. Counts for codes related to employability

\begin{tabular}{|c|c|c|c|}
\hline Dimensions & Codes & & Counts \\
\hline & Easier to achieve & & 2 \\
\hline & Career progression/development & & 8 \\
\hline \multirow[t]{7}{*}{ First degree } & Compression & & 20 \\
\hline & Lack of maturity & & 4 \\
\hline & Sufficient for employment & & 12 \\
\hline & Insufficient & & 39 \\
\hline & & Public opinion perceptions & 17 \\
\hline & & Own unpreparedness & 22 \\
\hline & Essential for employment & & 8 \\
\hline \multirow{7}{*}{$\begin{array}{l}\text { Responsibility } \\
\text { for } \\
\text { employability }\end{array}$} & Policy-makers & & 3 \\
\hline & Employers & & 13 \\
\hline & Higher education institutions & & 15 \\
\hline & Students & & 20 \\
\hline & External factors & & 63 \\
\hline & & Employer preferences & 24 \\
\hline & & Employment characteristics & 20 \\
\hline \multirow{9}{*}{$\begin{array}{l}\text { Employability } \\
\text { concept }\end{array}$} & & Macro-economic situation & 9 \\
\hline & & Labour market & 10 \\
\hline & Individual factors & & 62 \\
\hline & & Differentiation from others & 4 \\
\hline & & Personal competences & 26 \\
\hline & & Field related skills and knowledge & 7 \\
\hline & & Job seeking skills & 2 \\
\hline & & Practical/work experience & 13 \\
\hline & & Soft skills & 10 \\
\hline
\end{tabular}

Regarding disciplinary differences, Arts students held employers as the main responsible for their employability, while Engineering students saw themselves as the main responsible agents. This may be linked to the labour market opportunities available to these two student groups. While the labour market destinations are opaque and blurred for Arts students, the disciplinary area of Computer Engineering students has a relatively clear correspondence with a labour market niche. Therefore, it appears plausible that Arts students should hold employers responsible, while Computer Engineering students place the onus on themselves. 
This assumption could be further corroborated by the way in which students interpret employability. According to the literature, employability is understood as a multi-faceted concept which comprises both individual and external factors, determining the likelihood of being successful in the job market (Brown et al. 2003; McQuaid and Lindsay 2005). Given students' feeling of unpreparedness and self-responsabilty for employability, one could expect individual factors to weigh more heavily than external factors. However, students, in equal measure, referred to these two dimensions to describe their understanding of employability. On the one hand, students understood employability to be related to their possession of certain individual characteristics, such as: competences like versatility, proactivity and entrepreneurship, soft skills, field-related technical skills and knowledge, and the ability to stand out among other students. On the other hand, students are facing adverse circumstances, that is a precarious labour market further to a difficult macroeconomic situation in southern European countries (Scarpetta et al. 2010; Cairns et al. 2014; Cutuli and Guetto 2012). This may explain the balance between external and internal factors found in this study. Should the external circumstances be less hostile, the weight of individual factors would probably be more evident. Among the external factors considered to be influencing employability, the following stood out: employer preferences (in terms of the higher education institution and discipline); employment characteristics related to students' expectations of a certain quality of employment (match with the study area, stability, income, and career progression); labour market; and macro-economic situation.

A difference emerged between the perceptions of students in public and private institutions. The former, in a larger degree, stressed the individual factors as determinant for their employability. Associated with the fact that these students are also the ones who have higher expectations of the quality of employment, these findings suggest that public sector students are less affected by graduate unemployment as a consequence of the economic crisis. The hierarchy in the perceived value of higher education institutions, where public ones are regarded more highly than private ones (Tavares and Cardoso 2013), is therefore likely to be replicated in students' employment opportunities. 


\section{Conclusion}

This paper aimed to investigate student perceptions of the reasons why the first degree is insufficient for the labour market. Overall findings suggest that, according to students, the poor value of the first degree is explained by their individual inability to respond to labour market needs rather than by public scepticism about the degree's worth. In fact, students seem to consider themsleves unprepared to start working, given the insufficiency of the acquired knowledge and competences in the now shorter first degree. This is a noteworthy finding about the perceived consequences of the foreshortening of the first degree as a result of the Bologna reforms. The intended paradigm shift towards student-centred learning and learning outcomes appears not to have borne fruit, judging by students' perceptions. Therefore, institutions may not have done a proper and thorough reform of the degrees to achieve Bologna's ambition that the first degree should be relevant for the labour market. This is an important finding for institutions and programme leaders who could rethink their curricula, should they see employability as part of their mission.

Although their feeling of unpreparedness to enter the job market appears to have been triggered by supposedly unsuccessfully implemented educational policies, students continue to place themselves in the driver seat when it comes to their employability. The other findings reinforce the fact that students look primarily towards themselves when making sense of employability (or lack of). Overall, they see themselves as the key agents responsible for employability and emphasise the individual factors behind the concept, although the force of the economic crisis has balanced the weight between individual and external factors. This suggests that policy-makers could also take measures to help graduates' transition to the labour market.

\section{References}

Amaral, A., \& Magalhães, A. (2004). Epidemiology and the Bologna Saga. Higher Education, 48, 79-100.

Becher, T., \& Trowler, P. (2001). Academic tribes and territories: Intellectual enquiry and the culture of disciplines. McGraw-Hill Education (UK).

Bridgstock, R. (2009). The graduate attributes we've overlooked: enhancing graduate employability through career management skills. Higher Education Research and Development, 28(1): 31-44.

Brown, P., A. Hesketh, and S. Williams. (2003). Employability in a Knowledge-driven Economy. Journal of Education and Work 16 (2): 107-126.

Cai, Y. (2013). Graduate employability: a conceptual framework for understanding employers' perceptions. Higher Education, 65(4): 457-469. 
Cairns, D., Growiec, K., \& de Almeida Alves, N. (2014). Another 'missing middle'? The marginalised majority of tertiary-educated youth in Portugal during the economic crisis. Journal of Youth Studies, 17(8), 1046-1060.

Cardoso, J. L., Varanda, M., Madruga, P., Escária, V., \& Ferreira, V. S. (2012). Empregabilidade e Ensino Superior em Portugal. Lisboa: Agência de Avaliação e Acreditação do Ensino Superior (A3ES).

Cutuli, G., \& Guetto, R. (2013). Fixed-term contracts, economic conjuncture, and training opportunities: a comparative analysis across European labour markets. European Sociological Review, 29(3), 616-629.

Fugate, M., Kinicki, A. J., \& Ashforth, B. E. (2004). Employability: A psycho-social construct, its dimensions, and applications. Journal of Vocational behavior, 65(1): 1438.

Holmes, L. (2013). Competing perspectives on graduate employability: possession, position or process?, Studies in Higher Education 38(4): 538-554.

Jackson, D. (2014). Factors influencing job attainment in recent bachelor graduates: evidence from Australia. Higher Education, 68(1): 135-153.

McQuaid, R., and Lindsay C. (2005). The Concept of Employability. Urban Studies 42 (2): 197-219.

Rothwell, A., Herbert, I., \& Rothwell, F. (2008). Self-perceived employability: Construction and initial validation of a scale for university students. Journal of vocational behavior, 73(1): 1-12.

Scarpetta, S., A. Sonnet and T. Manfredi (2010). Rising Youth Unemployment During The Crisis: How to Prevent Negative Long-term Consequences on a Generation?, OECD Social, Employment and Migration Working Papers, No. 106, OECD Publishing, Paris.

Schomburg, H., \& Teichler, U. (2011). Employability and mobility of bachelor graduates in Europe. Rotterdam: Springer.

Sin, C., Tavares, O., \& Amaral, A. (2016a). Student perceptions of the employability of the first degree in Portugal. Education+ Training, 58(9), 966-983

Sin, C., Tavares, O., \& Amaral, A. (2016b). Who is responsible for employability? Student perceptions and practices. Tertiary Education and Management, 22(1), 65-81.

Strauss, A., \& Corbin, J. M. (1990). Basics of Qualitative Research: Grounded Theory Procedures and Techniques. Thousand Oaks, CA: Sage.

Tavares, O., \& Cardoso, S. (2013). Enrolment choices in Portuguese higher education: do students behave as rational consumers?. Higher Education, 66(3), 297-309.

Thrupp, M. (1998). Exploring the politics of blame: School inspection and its contestation in New Zealand and England. Comparative education, 34(2), 195-209.

Van der Heijde, C. M., \& van der Heijden, B. I. (2006). A competence- based and multidimensional operationalization and measurement of employability. Human resource management, 45(3): 449-476.

Vieira, D.A. \& Marques, A. P. (2014). Preparados para trabalhar? [Prepared for work?]. Porto: Forum Estudante. Consórcio Maior Empregabilidade. 